\title{
Protective Effect of Lemon Grass (Cymbopogon citratus) Water Extract Against Nephrotoxicity Induced by Cisplatin of Male Rats
}

\author{
Mohammed H. Haggag \\ Nutrition and Food Science Department, Faculty of Home Economics, Helwan \\ University, Cairo, Egypt.
}

\begin{abstract}
The present study was conducted in order to examine the protective effect of lemon grass (Cymbopogon citratus) water extract (LGWE) against nephrotoxicity induced by cisplatin of male Albino rats. Thirty five adult male Albino rats weighing between 120-140g were randomly separated into five different groups (7rats each). Group1 was a normal control group (-ve), fed on basal diet. Group 2 was the positive control group (+ve) fed on basal diet for 6 weeks and then injected intraperitoneally (i.p.) with a single dose of cisplatin $5 \mathrm{mg} / \mathrm{kg}$ of body weight. Groups 3,4 and 5 fed the same as group2 and received 5, 7.5 and 10\% lemon grass water extract, respectively, for 6 weeks and then injected intraperitoneally (i.p.) with the same dose of cisplatin. Five days later all rats in all groups were sacrificed and the blood was collected for biochemical and histopathological investigations. Cisplatin treatment caused significantly increase in serum malondialdehyde, uric acid, blood urea nitrogen and creatinine as well as alanine aminotransferase, aspartate aminotransferase and alkaline phosphatase $(p<0.05)$ in +ve control group compared to -ve control group. Rats which were fed LGWE (groups 3, 4 and 5) showed marked reduction in the same biochemical investigations compared to +ve control group. Reduced glutathione (GSH), serum sodium and potassium mean values were decreased in +ve control group compared to -ve control rats. Feeding LGWE in groups 3,4 and 5 showed a rise in the same biochemical parameters compared to +ve control group. 2, 2-Diphenyl-1-picrylhydrazyl (DPPH), half maximal inhibitory concentration $\left(\mathrm{IC}_{50}\right)$ and total phenolic content of lemon grass was assayed. Parallel to the above mentioned changes, cisplatin treatment enhances renal damage as evidenced by sharp impairment of kidney function corresponds to biochemical parameters and histopathological findings. Additionally, feeding LGWE caused gradually histopathological improvement in renal tissues in groups 3,4 and 5. These results of this present study indicated that aqueous extracts of Cymbopogon citratus has antinephrotoxic properties against cisplatin induced renal oxidative damage in rats which might be ascribed to its antioxidant and free radical scavenging property. According to these above results, it is recommended to conduct further studies on the use of LGWE and possible protection of human beings against nephrotoxicity.
\end{abstract}

\section{Introduction}

A number of environmental contaminants, chemicals and drugs including antibiotics dramatically alter the structure and function of various tissues and produce multiple adverse effects in the liver, kidney, heart and intestine. Among various species with medical properties Cymbopogon citratus, a species popularly known as" Lemon grass" which is an economically important aromatic perennial plant of the Poaceae family that has been used to extract essential oils. It is grown around the world and has a century -long record of extensive therapeutic applications in traditional and Ayurvedic medicine in a number of countries. It is used as a herbal medicine for a wide range of applications based on its antibacterial, antifungal, antiprotozoal, anti-carcinogenic, anti-inflammatory, antioxidant, cardio protective, antitussive, antiseptic, and anti-rheumatic activities (Tarkang et al., 2012). It has also been used to inhibit platelet aggregation, treat diabetes, dyslipidemia, gastrointestinal disturbances, anxiety, malaria, flu, fever, and 
pneumonia, as well as in aromatherapy(Tchoumbougnang et al.,2005). In addition to its therapeutic uses, C. citratus is also consumed as a tea, added to non-alcoholic beverages and backed food, and used as a flavoring and preservative in confections and cuisines. In cosmetics, its essential oils are used as fragrance in the manufacture of perfumes, soaps, detergents, and creams (Ekpenyong et al.,2014). The isolated and identified substances from the leaves are mainly alkaloids, saponin, asitosterol terpenes, alcohols, ketone, flavonoids, chlorogenic acid, caffeic acid, p-coumaric acid and sugars( Negrelle and Gomes, 2007).

In the same time cisplatin is an effective chemotherapeutic agent for a wide variety of tumors (Park et al., 2009). Nevertheless, it has several side effects including hepatotoxicity (Mansour et al., 2006; Pratibha et al., 2006) and nephrotoxicity (Park et al., 2009).Vaccines, steroids and antiviral drugs, which are commonly used for treating liver diseases, have been found to have side effects and complications to human health, especially when administered chronically or sub-chronically. Therefore, herbal products and traditional medicines with better effectiveness and safe profiles are needed as a substitute for chemical therapeutics. As oxidative stress it plays a central role in liver pathologies and their progression, the use of antioxidants has been proposed as therapeutics agents to counteract liver damage (Pei et al, 2012).

This study was aimed to study the protective effect of LGWE against nephrotoxicity induced by cisplatin of male rats.

\section{Materials and Methods}

Materials:

Thirty five adult male Albino rats (120-140 g) were obtained from Animal House Colony of Vacsera, Helwan, Agriculture Research Center, Egypt. They were housed in stainless steel cages under a $12 \mathrm{~h} \mathrm{light}$ - dark cycle at $20 \pm 5^{\circ} \mathrm{C}$. Animals were maintained at free access to tap water and were fed a basal diet for at least 7 days before starting the experiment. Casein, cholesterol, cellulose, all vitamins and minerals were obtained from El-Gomhoriya Pharmaceutical Company, Cairo, Egypt. Lemon grass, starch and soy oil were obtained from the local market. Dried leaves of lemon grass were milled into fine powder from which $50 \mathrm{~g}$ was soaked in $500 \mathrm{ml}$ of distilled water in a beaker and the mixture shaken and kept on normal room temperature for $24 \mathrm{~h}$. The basal diet was prepared according to Reeves et al., 1993.

\section{Experimental design:}

After one week of adaptation, rats were divided into 5 main groups (7rats each). Group1 was a normal control group (-ve), fed on basal diet. Group 2 was the positive control group (+ve) fed on basal diet for 6 weeks and then injected intraperitoneally (i.p.) with a single dose of cisplatin $5 \mathrm{mg} / \mathrm{kg}$ of body weight (Mansour et al., 2006). Groups 3,4 and 5 fed the same as group2 and received 5, 7.5 and 10\% lemon grass water extract, respectively, for 6 weeks and then injected intraperitoneally (i.p.) with the same dose of cisplatin. Five days later all rats in all groups were sacrificed and the blood was collected for various biochemical estimations. Feed intake was recorded daily at the experimental period. Body weight gain and feed efficiency ratio were calculated according to Hsu et al., (1978).

\section{Methods of analysis:}

Blood urea nitrogen, creatinine and uric acid were assayed spectrophotomitrically at $546 \mathrm{~nm}$ according to Kaplan , (1984) ; Murray, (1984) and Fossati et al., (1980), respectively. Serum aspartate aminotransferase, alkaline aminotransferase and alkaline phosphatase were measured according to the method of Murray,1984,at 505 nm. Malondialdehyde was measured according to Ohkawa et al., 1979. Glutathione (GSH) was measured according to Nishkimi et al., 1972.

Folin Ciocalteu reagent was used for analysis of total phenolic contents (TPC) according to Chun et al., (2003). TPC was expressed as $\mathrm{mg}$ gallic acid equivalent per gram of sample. 2,2-Diphenyl-1-picrylhydrazyl (DPPH) radical 


\section{Egypt. J. of Nutrition and Health Vol. 10 No. 1 (2015)}

scavenging activity was assayed according to Kikuzaki et al., (2002). The scavenging effect on the DPPH radical was read using spectrophotometer at $517 \mathrm{~nm}$. The radical scavenging activity was expressed as the radical scavenging percentage. Half maximal inhibitory concentration $\left(\mathrm{IC}_{50}\right)$ value is the concentration of sample required to scavenge $50 \%$ of DPPH free radical and was calculated from the plotted graph of radical scavenging activity against the concentration of extract. The DPPH solution without sample solution was used as control.

\section{Histopathological Examination:}

Autopsy samples were taken from the kidney of rats in different groups and fixed in $10 \%$ formalin solution for twenty four hours. Washing was done in tap water then dehydrated in graded (50\%-100\%) alcohol. Specimens were cleared in xylene and embedded in paraffin at 56 degree in hot air oven for twenty four hours. Paraffin bees wax tissue blocks were prepared for sectioning at 4 microns thickness by sledge microtome. The obtained tissue sections were collected on glass slides, deparaffinized, and stained by hematoxylin and eosin stain for examination through the light electric microscope Banchroft et al., (1996).

\section{Statistical analysis of data:-}

Data were statistically analyzed using statistical analysis system (SAS, 2006). One way analysis of variance (ANOVA) was used to test the variations among groups. The difference was considered significant when the $P$ value less than 0.05 .

\section{Results and Discussion}

Animal model of cisplatin induced nephrotoxicity was used for the present study. There was a significant decrease $(P<0.05)$ in feed intake in cisplatin treated rats (+ve control) when compared with the normal (-ve control) rats (Table 1). Rats exposed to the various concentrations of aqueous extract of LGWE their feed intake significantly improved when compared to the cisplatin +ve control and reached close to the level of -ve control. Ten percent LGWE showed the best feed intake (Table1).

In the respect of BWG, Table (1) indicate that body weight significantly decreased from 2.14 in -ve control group to 1.79 in +ve control group as a result of cisplatin injection. Body weight gain of rats that received LGWE improved to reach the same BWG of rats in group 1. The highest mean value was recorded at feeding level of $10 \%$ LGWE. Feed efficiency ratio (FER) was significantly decreased to 0.17 for +ve control compared to 0.18 for the - ve control (Table1). On increasing the amount of LGWE the FER increased.

These results, in respect with loss of body weight, agree with the result reported by Ullah et al., 2013, who investigated the renal protective effect of lemon grass in gentamicin induced nephrotoxicity in rabbits, it also protected alteration in body weight.

Data presented in Table (2) show that cisplatin injected rats (+ve control group) had higher mean values of uric acid, blood urea nitrogen and creatinine compared to -ve control rats in group1. Rats feeding LGWE at the concentrations of $5,7.5$ and $10 \%$ lowered these values to be near the -ve control values (Table2). The best mean value $2.03 \pm 0.22 \mathrm{mg} / \mathrm{dl}$ was observed in $10 \% \mathrm{LGWE}$ feeding rats. The mean values of BUN and creatinine showed the same findings of feeding $10 \%$ LGWE.

Assessment of serum creatinine and BUN was carried out to test the renal function and as a marker of glomerular and tubular damage (Thamilselvan and Menon, 2005). Estimation of BUN has been thought to be the most important biomarker for the assessment of renal injury (Guyton, 1991). Blood urea nitrogen increased significantly in cisplatin treated rats in group $2(57.12 \pm 3.89$ vs. - ve control group $17.61 \pm 2.08 \mathrm{mg} / \mathrm{dl})$ on the last day of study period. 
Serum creatinine was also increased significantly in + control group as given in Table (2). The relation between serum creatinine and tubular necrosis has also been presented (attached histopathology photos), with the suggestion that necrotic debris in the lumen of tubules might be responsible for the elevation of serum creatinine (Solez, 1983).

Serum uric acid is the final metabolite of purine; therefore, any change in glomerular filtration rate (GFR) may lead to increase serum uric acid (Meena et al., 2009). As cisplatin induced renal damage is associated with significant rise in serum BUN and serum creatinine and fall in GFR (Bennett et al., 1991)

The marked decrease in uric acid, BUN and creatinine with administration of LGWE was in agreement with studies by other researchers (Mansour et al., 2006; Nagizadeh et al., 2008; Ibrahim et al., 2010). Noori and Mahboob, (2010) reported that administration of cisplatin to rats caused a reduction in glomerular filtration rate (GFR), which correlated with increased creatinine and urea in plasma. This is in agreement with the present study which showed that cisplatin caused a reduction in (GFR), correlated with alteration in the renal function as indicated by the different values of renal markers.

Serum aspartate aminotransferase (AST), alanine aminotransferase (ALT) and alkaline phosphatase (ALP) mean values increased significantly $(P<0.05)$ in the group treated with cisplatin (+ve control) compared with -ve control rats, which showed the values $98.74 \pm 9.08$ vs $54.63 \pm 7.23 \mathrm{U} / \mathrm{L}$, respectively, for AST (Table3). Whereas, AST concentration in blood serum of rats feeding LGWE before cisplatin injection showed a gradual decrease starting from $5 \%$ LGWE and ended by the 10\% LGWE. More or less, the same trend can be seen in respect of ALT in all groups. On the other side ALP showed a mean value of $180.55 \pm 12.09$ and $260.49 \pm 14.52 \mathrm{U} / \mathrm{L}$ for $-\mathrm{ve}$ and +ve control groups, respectively. Increasing LGWE concentration in feeding rats resulted in decreasing the ALP mean values parallel to the increase of feeding LGWE. The best results can easy be seen at the level of $10 \%$ LGWE (Table3).

Cisplatin, a heavy metal complex is an effective chemotherapeutic agent for a wide variety of diseases. It has several toxicities and side effects including hepatotoxicity (Mansour et al.,2006) and nephrotoxicity (Park et al.,2009). Recent studies have been focused on the ways for protection of cisplatin hepatotoxicity; however, little has been reported regarding the use of lemon grass aqueous extract. Pei et al., 2012, reported the hepatoprotective effect of lemon grass. The marked decrease in the activities of the three marked enzymes ALT, AST and ALP with feeding LGWE in this research may be due to the hepatoprotective effect of lemon grass.

Addition of lemon grass or its oil to diet improved the nutritional value and the mean values of AST and ALT decreased in all treated rats with lemon grass. High level of lemon grass or its oil showed the best effect on kidney and liver functions (Eman El-Sayed, 2011).

To ascertain the oxidative status of the experimental animals feeding LGWE, GSH and MDA were assessed (Table 4). The results obtained for the effect of extracts of lemon grass at $5,7.5$ and $10 \%$ concentration of serum levels of primary products of lipid peroxidation (MDA) and GSH are presented in Table(4). Treatment of experimental rats with cisplatin (+ve control) produced a significant increase $(P<0.05)$ in the level of MDA in the serum $(47.75 \pm 2.75 \mathrm{nmol} / \mathrm{ml})$ when compared with -ve control group $(22.36 \pm 1.84 \mathrm{nmol} / \mathrm{ml})$. Feeding of $5,7.5$ and $10 \%$ LGWE before cisplatin injection resulted in a gradually inhibition of MDA elevation which recorded $39.44 \pm 2.06,31.68 \pm 2.00$ and $26.91 \pm 1.95 \mathrm{nmol} / \mathrm{l}$ for groups 3,4 and 5, respectively. This result is an indication of the prevention effect of LGWE against nephrotoxicity of experimental rats. These results suggest that lemon grass play a role in peroxidation by inhibiting free radical attacks on bio membranes (Ojo et al., 2006). On the other hand treatment of experimental animals with cisplatin (+ve control) produced a significant decrease in the serum GSH (reduced form of glutathione) as a result of cisplatin injection. Rats fed LGWE recorded $9.98 \pm 1.05,10.76 \pm 1.01$ and $12.05 \pm 1.34 \mathrm{nmol} / /$ at $5,7.5$ and $10 \%$ LGWE concentration. As the concentration of extract increased, a gradual increase in GSH occurred. 


\section{Egypt. J. of Nutrition and Health Vol. 10 No. 1 (2015)}

Badary et al., 2005, also reported that naringenin, a naturally citrus flavonone reduced the extent of cisplatin induced nephrotoxicity, as evidenced by significant marked reduction in glutathione-S-transferase activity. The results provide further agreement with results reported in this paper.

The impairment in kidney functions was accompanied by an increase of MDA contents in Kidney tissue (Isaac et al., 2014) and an impaired activity of the antioxidant enzymes as reported by Kadikoylu et al., 2004. These results are also in agreement with previous studies of Isaac et al.,2014, who reported marked elevation in the MDA levels and decreased in the antioxidant activities in rat's kidney tissues. The marked reduction in oxidative stress and lipid peroxide (reduced glutathione and MDA) with the administration of LGWE is in agreement with the work by Ojo et al., 2006, who reported the antioxidative properties of $L G$ in paracetamol induced oxidative stress in rats.

Epidemiological studies have shown a diminished risk of chronic diseases in populations consuming diets high in fruits and vegetables (Pryor et al., 2000). It has been suggested that antioxidants found on large quantities in these foods may be responsible for this protective effect (Halliwell, 1994). Generally, lemon grass antioxidants act as reducing agents, reversing oxidation by donating some antioxidants such as polyphenols (Murray, 1995). Omotade, 2009, reported that the leaves of lemon grass contained flavonoids which reported to exhibit antioxidant activity.

Kidneys actively reabsorb or excrete electrolytes to maintain the electrolyte balance of the body. Owing to small size, almost all electrolytes are filtered at glomerulus. After filtration most of the electrolytes are absorbed back at the tubular level but any problem at the tubular level will result in nonabsorption and excessive loss of electrolytes in urine. The results obtained for the protective effects of LGWE on serum levels of sodium $\left(\mathrm{Na}^{+}\right)$and potassium $\left(\mathrm{K}^{+}\right)$are presented in Table (5). Feeding experimental rats with LGWE up to the level of $10 \%$ significantly reversed the level of $\mathrm{Na}^{+}$and $\mathrm{K}^{+}$to approximate normal value. The results showed insignificant different values (153.2 \pm 2.9 for - ve group vs. $150.3 \pm 1.3$ for $10 \%$ LGWE whereas the values of $\mathrm{K}^{+}$in spite of its increase due to feeding of LGWE it showed a significant less values (Table 5). Gradual increasing LGWE results in gradual increase in $\mathrm{Na}^{+}$and $\mathrm{K}^{+}$levels of blood serum compared to +ve control group. It was reported that hypokalemia is a common electrolyte abnormality that occurs in cisplatin treatment (Surinder et al., 2010), it is due to increased renal reabsorption capacity observed in response to decrease intestinal absorption of potassium. Further metabolism subjected to predicable changes in intestinal absorption and renal excretion with each cisplatin treatment (Xin et al., 2007). Serum potassium decreased has also been reported and is thought to be owing to the depression of $\mathrm{Na}^{+}-\mathrm{K}^{+}-\mathrm{ATPase}$ activity.

The values of antioxidant activities using 2, 2-diphenyl-1-picrylhydrazyl (DPPH) radical scavenging and the determination of LG phenolic content were assessed in Table(6). Lemon grass can strongly scavenge DPPH radical with $I_{50}$ of $9.88 \mathrm{mg} / \mathrm{g}$. Phenolic compounds $(1.21 \mathrm{mg} / \mathrm{g})$ contribute to the overall antioxidant activities (Table 6). The mechanisms of phenolic compounds antioxidant activity are neutralizing lipid free radicals and preventing decomposition of hydroperoxides into free radicals (Li et al., 2009).

The parameter used to measure the radical scavenging activity of extracts is to determine the $\mathrm{IC}_{50}$ value defined as the concentration of antioxidant required for $50 \%$ scavenging of DPPH radicals in the specific time period (reported after $30 \mathrm{~min}$ reaction).It was reported that the smaller $I C_{50}$ value, the higher antioxidant activity of the extract(Maisuthisakul et al., 2007). These results show that lemon grass has a detectable concentration of antioxidant which may be owing to the protective effect against nephrotoxicity.

\section{Histopathological Findings:}

There was no histopathological alteration and the normal histological structure of the glomeruli and tubules at the cortex were recorded in -ve control group (Photo,1). Degeneration and necrosis, were observed in the tubular lining epithelium associated with focal fibrosis in between and congestion in glomerular tufts of rats in +ve control group (Photo,2). Likewise there was focal inflammatory cells infiltration as well as congestion in the blood vessels in between 
the tubules in the same group. In rats fed 5\% LGWE, focal fibrosis and hyalinization were detected in between the degenerated tubules at the cortex (Photo,3). There was congestion in the blood vessels and glomerular tufts associated with focal few fibrosis in between the degenerated tubules of rats fed $7.5 \%$ LGWE before cisplatin injection (Photo,4). Focal few inflammatory cells infiltration was noticed in between the degenerated tubules associated with congestion in the blood vessels and glomeruli in rats received 10\%LGWE (Photo,5). These histopathological findings were further confirmed by evidence of biochemical investigations which emphasize the LGWE protective role against nephrotoxicity.

\section{Conclusion}

In conclusion, the results of this present study indicated that aqueous extract of Cymbopogon citratus has antinephrotoxic properties against cisplatin induced renal toxicity of rats which may be ascribed to its antioxidant and free radical scavenging properties which may help in the inhibition of oxidative stress injury of kidneys.

Table (1):

Effect of lemon grass water extract at different levels on feed intake (FI), body weight gain (BWG) and feed efficiency ratio (FER) of rats

\begin{tabular}{|llllll|}
\hline Parameters & -ve Control & +ve Control & $+5 \%$ LGWE & $+7.5 \%$ LGWE & $+10 \%$ LGWE \\
\hline FI (g/d) & & & & & \\
BWG & $11.97 \pm 1.05^{\mathrm{a}}$ & $10.56 \pm 1.32^{\mathrm{b}}$ & $10.98 \pm 0.99^{\mathrm{a}}$ & $11.00 \pm 1.21^{\mathrm{a}}$ & $11.39 \pm 0.78^{\mathrm{a}}$ \\
FER & $2.14 \pm 0.06^{\mathrm{a}}$ & $1.79 \pm 0.03^{\mathrm{b}}$ & $2.00 \pm 0.10^{\mathrm{a}}$ & $2.21 \pm 0.02^{\mathrm{a}}$ & $2.35 \pm 0.14^{\mathrm{a}}$ \\
\hline
\end{tabular}

All results are expressed as mean $\pm \mathrm{SE}$.

Values in each row which have different letters are significantly different $(p<0.05)$

Table (2):

Effect of lemon grass water extract at different levels on uric acid, blood urea nitrogen (BUN) and creatinine of rats

\begin{tabular}{|llllll|}
\hline Parameters & -ve Control & +ve Control & $+5 \%$ LGWE & $+7.5 \%$ LGWE & $+10 \%$ LGWE \\
\hline Uric acid $(\mathrm{mg} / \mathrm{dl})$ & $1.90 \pm 0.04^{\mathrm{d}}$ & $3.08 \pm 0.45^{\mathrm{a}}$ & $2.91 \pm 0.37^{\mathrm{b}}$ & $2.61 \pm 0.19^{\mathrm{b}}$ & $2.03 \pm 0.22^{\mathrm{c}}$ \\
\hline BUN $(\mathrm{mg} / \mathrm{dl})$ & $17.61 \pm 2.08^{\mathrm{e}}$ & $57.12 \pm 3.89^{\mathrm{a}}$ & $42.35 \pm 3.26^{\mathrm{b}}$ & $30.99 \pm 4.00^{\mathrm{c}}$ & $21.55 \pm 2.17^{\mathrm{d}}$ \\
\hline Creatinine $(\mathrm{mg} / \mathrm{dl})$ & $01.02 \pm 0.05^{\mathrm{c}}$ & $03.28 \pm 0.02^{\mathrm{a}}$ & $02.14 \pm 0.05^{\mathrm{b}}$ & $02.00 \pm 0.01^{\mathrm{b}}$ & $01.51 \pm 0.04^{\mathrm{c}}$ \\
\hline
\end{tabular}

All results are expressed as mean $\pm \mathrm{SE}$.

Values in each row which have different letters are significantly different $(p<0.05)$. 
Egypt. J. of Nutrition and Health Vol. 10 No. 1 (2015)

Table (3):

Effect of lemon grass water extract at different levels on aspartate aminotransferase (AST), alanine aminotransferase (ALT) and alkaline phosphatase

$(A L P)$ in blood serum of rats

\begin{tabular}{|llllll|}
\hline $\begin{array}{l}\text { Parameters } \\
(\mathrm{U} / \mathrm{L})\end{array}$ & -ve Control & + ve Control & $+5 \%$ LGWE & $+7.5 \%$ LGWE & $+10 \%$ LGWE \\
\hline AST & $54.63 \pm 7.23^{\mathrm{c}}$ & $98.74 \pm 9.08^{\mathrm{a}}$ & $74.27 \pm 6.95^{\mathrm{b}}$ & $63.09 \pm 5.69^{\mathrm{c}}$ & $59.13 \pm 5.08^{\mathrm{c}}$ \\
\hline ALT & $39.76 \pm 6.22^{\mathrm{d}}$ & $81.07 \pm 7.95^{\mathrm{a}}$ & $62.88 \pm 4.79^{\mathrm{b}}$ & $53.65 \pm 4.52^{\mathrm{c}}$ & $42.02 \pm 3.99^{\mathrm{d}}$ \\
\hline ALP & $180.55 \pm 12.09^{\mathrm{d}}$ & $260.49 \pm 14.52^{\mathrm{a}}$ & $210.09 \pm 12.98^{\mathrm{b}}$ & $198.99 \pm 12.07^{\mathrm{c}}$ & $190.74 \pm 11.75^{\mathrm{c}}$ \\
\hline
\end{tabular}

All results are expressed as mean $\pm \mathrm{SE}$.

Values in each row which have different letters are significantly different $(p<0.05)$.

Table (4):

Effect of lemon grass water extracts at different levels on reduced glutathione (GSH), malondialdehyde (MDA) and total antioxidant of rats

\begin{tabular}{|llllll|}
\hline Parameters & -ve Control & +ve Control & $+5 \%$ LGWE & $+7.5 \%$ LGWE & $+10 \%$ LGWE \\
\hline GSH $(\mathrm{nmol} / \mathrm{ml})$ & $13.08 \pm 1.73^{\mathrm{a}}$ & $7.64 \pm 0.99^{\mathrm{c}}$ & $9.98 \pm 1.05^{\mathrm{b}}$ & $10.76 \pm 1.01^{\mathrm{b}}$ & $12.05 \pm 1.34^{\mathrm{a}}$ \\
\hline $\mathrm{MDA}(\mathrm{nmol} / \mathrm{ml})$ & $22.36 \pm 1.84^{\mathrm{d}}$ & $47.75 \pm 2.75^{\mathrm{a}}$ & $39.44 \pm 2.06^{\mathrm{b}}$ & $31.68 \pm 2.00^{\mathrm{c}}$ & $26.91 \pm 1.95^{\mathrm{c}}$ \\
\hline
\end{tabular}

All results are expressed as mean \pm SE.

Values in each row which have different letters are significantly different $(p<0.05)$.

Table (5):

Effect of lemon grass water extract at different levels on serum sodium, serum potassium of rats

\begin{tabular}{|lccccc|}
\hline Parameters & -ve Control & +ve Control & $+5 \%$ LGWE & $+7.5 \%$ LGWE & $+10 \%$ LGWE \\
\hline Serum sodium $(\mathrm{mEq} / \mathrm{l})$ & $153.2 \pm 2.9^{\mathrm{a}}$ & $141.1 \pm 1.8^{\mathrm{c}}$ & $144.3 \pm 1.1^{\mathrm{b}}$ & $148.76 \pm 1.4^{\mathrm{b}}$ & $150.3 \pm 1.3^{\mathrm{a}}$ \\
\hline Serum potassium $(\mathrm{mEq} / \mathrm{l})$ & $9.64 \pm 0.8^{\mathrm{d}}$ & $7.51 \pm 0.5^{\mathrm{a}}$ & $7.99 \pm 0.6^{\mathrm{b}}$ & $8.31 \pm 1.1^{\mathrm{c}}$ & $8.97 \pm 1.5^{\mathrm{c}}$ \\
\hline
\end{tabular}

All results are expressed as mean \pm SE.

Values in each row which have different letters are significantly different $(p<0.05)$. 
Table (6):

2,2-Diphenyl-1-picrylhydrazyl (DPPH), half maximal inhibitory concentration $\left(\mathrm{IC}_{50}\right)$ and total phenolic content of Lemon grass water extract

\begin{tabular}{|c|c|c|}
\hline DPPH (\% antioxidant) & Total phenolic Compound $(\mathrm{mg} / \mathrm{g})$ & $\mathrm{IC}_{50}(\mathrm{mg} / \mathrm{g})$ \\
\hline 49.41 & 1.21 & 9.88 \\
\hline
\end{tabular}

Table (7):

The severity of histopathological alterations in kidney of different experimental groups

\begin{tabular}{|c|c|c|c|c|c|}
\hline Histopathological alterations & 1 & 2 & 3 & 4 & 5 \\
\hline Degeneration & - & +++ & ++ & + & + \\
\hline Necrosis & - & ++ & - & - & - \\
\hline Focal sub-acute interstitial nephritis & - & ++ & + & + & - \\
\hline Congestion & - & ++ & - & ++ & ++ \\
\hline
\end{tabular}

\begin{tabular}{|c|c|c|}
\hline No. & Kidney Photos & Histopathological Findings \\
\hline 1 & 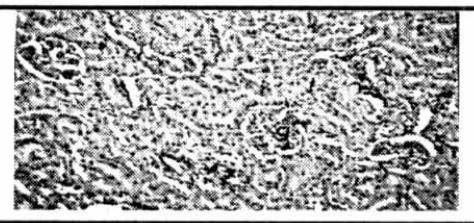 & $\begin{array}{l}\text { There was no histopathological alteration and the normal histological structure } \\
\text { of the glomeruli and tubules at the cortex were recorded }\end{array}$ \\
\hline 2 & 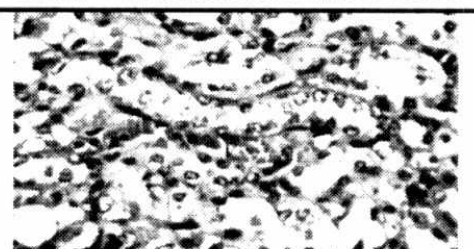 & $\begin{array}{l}\text { Degeneration and necrosis were observed in the tubular lining epithelium } \\
\text { associated with focal fibrosis in between and congestion in glomerular tufts. } \\
\text { There was focal inflammatory cells infiltration as well as congestion in the blood } \\
\text { vessels in between the tubules }\end{array}$ \\
\hline 3 & $x_{i=1}^{x+3}$ & $\begin{array}{l}\text { Focal fibrosis and hyalinization were detected in between the degenerated } \\
\qquad \text { tubules at the cortex }\end{array}$ \\
\hline 4 & 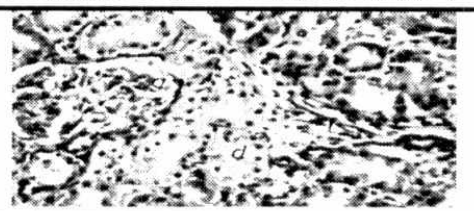 & $\begin{array}{l}\text { There was congestion in the blood vessels and glomerular tufts associated with } \\
\text { focal few fibrosis in between the degenerated tubules }\end{array}$ \\
\hline 5 & & $\begin{array}{l}\text { Focal few inflammatory cells infiltration was noticed in between the } \\
\text { degenerated tubules associated with congestion in the blood vessels and } \\
\text { glomeruli }\end{array}$ \\
\hline
\end{tabular}




\section{References}

Badary O.A., Abdel-Maksoud S., Ahmed W.A. and Owieda G.H.(2005):

Naringenin attenuates cisplatin nephrotoxicity in rats, Life Sciences, 76:2125-2135.

Banchroft J.D., Stevens A. and Turner D.R. (1996):

Theory and practice of histological techniques, Fourth Ed. Churchil Livingstone, New York, London, San Francisco, Tokyo.

Bennett W.M., Elzinga L.W.and Porter G.A.(1991):

Tubulointerstitial disease and toxic nephropathy. In: Brenner BM, Rector FC, editors. The Kidney. 4th ed.

Philadelphia: WB Saunders Company:1430-1496.

Chun O.K., Kim D.O. and Lee C.Y. (2003):

Superoxide radical scavenging activity of the major polyphenols in fresh plums. Journal Agriculture and Food Chemistry 51: 8067-8072.

Ekpenyong C.E., Akpan E.E. and Daniel N.E.(2014):

Phytochemical Constituents, Therapeutic Applications and Toxicological Profile of Cymbopogon citratus Stapf (DC) Leaf Extract.

Eman El-sayed M.(2011):

The protective effect of lemon grass and its oil on hepatotoxicity in rats caused by $\mathrm{CCl}_{4}$. The New Egyptian J. of Midicine:44:58-68.

Fossati P., Prencipe L. and Berti G. (1980):

Enzymatic colorimetric method for determination of uric acid in serum.Clin. Chem.; 26 (2): 227 - 273.

Guyton A.C. (1991):

Text Book of Medical Physiology. 8th ed. Philadelphia: WB Saunders Company; Renal disease, Diuresis and micturition: 344-354.

Halliwell B.(1994):

Antioxidant sence or speculation, Nutrition Today, 29:15-19.

Hsu H.W., Sutton N.E, Banjo M.O., Satterlee L.D. and Kendrick J.G. (1978):

The C-PER and assays for protein quality. J. FD. Technol., 12:69-74.

Ibrahim Y.M., Abdul B.A., Ibrahim T.T., Abdel-Wahab S.I. Elhassan, M.M. and Mohan S. (2010):

Attenuation of cisplatin $\square$ induced nephrotoxicity in rats using zerumbone.Afr.J. Biotech. 9:4434-4441.

Isaac A. A., Amos O. A., Blessing E. O., Isioma J. O., Abiola A. O., and Ebenezer O. F.(2014):

Impairment of hepatic and renal functions by 2,5 -hexanedione is accompanied by oxidative stress in rats, Journal of Toxicology,10:1-11. 
Kadikoylu G., Bolaman Z., Demir S., Balkaya M., Akalin N. and Enli Y. (2004):

The effects of desferrioxamine on cisplatin-induced lipid peroxidation and the activities of antioxidant enzymes in rat kidneys. Hum. Exp. Toxicol.,

3: 29-34.

Kaplan L.A. (1984).

lin Chem.The C.V. Mosby co.st Louis. Toronto. Princeton;1032-1036.

Kikuzaki H., Hisamoto M., Hirose K., Akiyama K. and Taniguchi H. (2002):

Antioxidants properties of ferulic acid and its related compounds. Journal Agriculture and Food Chemistry 50: 2161-2168.

Li H., Hao Z., Wang X., Huang L. and Li J.(2009):

Antioxidant activities of extracts and fractions from Lysimachia foenum-graecum Hance. Bioresource Technology 100: 970-974.

Maisuthisakul P., Suttajit M. and Pongsawatmanit R.(2007):

Assessment of phenolic content and free radicalscavenging capacity of some Thai indigenous plants. Food Chemistry 100: 1409-1418.

Mansour H.H., Hafez H.F. and Fahmy N.M.( 2006):

Silymarin modulates Cisplatin $10 \mathrm{mg} \mathrm{kg-1}$ platin induced oxidative stress and hepatotoxicity in rats. J. Biochem. Mol. Biol., 39: 656-661.

Meena M.K., Kushwah H.K., Rajagopala M.and Ravishankar B.(2009):

An experimental evaluation on nephroprotective activity of Nagaradi Kashaya. AYU,30:55-61.

Murray R. (1984):

Clin. Chem. the C. V. Mosby co. st Louis. Toronto. Princeton: 1088-1090.

Murray M.T.(1995):

The healing power of herps, London: Prima Publishing, 66-69.

Nagizadeh B., Boroushaki M.T., Vahdati Mashhadian N. and Mansouri M.T. (2008):

Protective effects of crocin against cisplatin-induced acute renal failure and oxidative stress in rats. Iran Biomed J., 12:93-100.

Negrelle R.R.B. and Gomes E.C.(2007):

Cymbopogon citratus (D.C) Stapf: chemical composition and biological activities. Rev Bras PI Med 9: 80-92.

Nishkimi M., Roa N.A. and Yogi K.(1972):

Biochem. Bioph. Res. Common., 46:849-854.

Noori S. and Mahboob T.(2010).

Antioxidative effects of carnosine pretreatment on cisplatin induced renal oxidative stress in rats. Indian $\mathrm{J}$. Clinical Biochem. 25:86-91. 


\section{Egypt. J. of Nutrition and Health Vol. 10 No. 1 (2015)}

Ohkawa H.,Ohishi W. and Yagi K.(1979):

Biochem.,95:351.

Ojo O.O. Kabutu F.R, Bello M. and Babayo U.( 2006):

Inhibition of paracetamol-induced oxidative stress in rats by extracts of lemongrass (Cymbropogon citrates) and green tea (Camellia sinensis) in rats, Afr. J. Biotechnol., 5: 1227-1232.

Omotade I.O.(2009):

Chemical profile and antimicrobial activity of Cymbopogon citratus leaves.Journal of Natural Products ,2:98-103.

Park H.R., Ju E.J., Jo S.K., Jung U., Kim S.H. and Yee S.T. (2009):

Enhanced antitumor efficacy of cisplatin in combination with HemoHIM in tumor-bearing mice. BMC Cancer, 9: $85-85$.

Pei H.K, Mokhtar R.A. and Mohammad I. (2012):

Antioxidant potential of Cymbopogon citratus extract: alleviation of carbon tetrachloride-induced hepatic oxidative stress and toxicity. Hum. Exp. Toxicol. 311:81-91.

Pratibha R., Sameer R., Rataboli P.V.D., Bhiwgade A. and Dhume C.Y. (2006):

Enzymatic studies of Cisplatin $10 \mathrm{mg} \mathrm{kg}$-1platin induced oxidative stress in hepatic tissue of rats. Eur. J. Pharmacol., 532: 290-293.

Pryor W., Stahl W. and Rock C. (2000):

Beta Carotene: From Biochem. to Clinical Trials. Nutr. Rev. 58: 39-53.

Reeves P., Nielsen F. and Fahmy G. (1993):

Report of The American Institute of Nutrition adhoc wriling committee on the reformulation of the AIN - 76 A Rodent diet. J. Nutr.; $123: 1939$ - 1951.

SAS. (2006):

Statistical Analysis System, SAS User's Guide: statistics. SAS Institute inc. Editors, Cary, NC.

Solez K.(1983):

International Review of Experimental Pathology. New York: Academic Press; Pathogenesis of acute renal failure: $321-326$.

Surinder A.,Balamurugan N. Gunaseelan K. et al.,(2010):

Adverse drug reaction profile of cisplatin based chemotheraby regimen in tertiary care hospital in India: An evaluation study, Indian J.Pharmacol.42:40-43.

Tarkang P.A., Agbor G.A., Tsabang N., Tchokouaha R.Y., Tchamgoue D.A.and Kemeta D. (2012):

Effect of long-term oral administration of the aqueous and ethanol leaf extract of Cymbopogon citratus (DC. Ex Ness) Stapf. Ann Biol Res; 3:5561-5570.

Tchoumbougnang F., Zollo P.H., Dagne E. and Mekonnen Y.(2005):

In vivo anti malaria activity of essential oils from Cymbopogon citratus and Ocimum gratissimum on mice injected with Plasmodium Berghei. Planta Medica; 71:20-23. 
Thamilselvan S. and Menon M.(2005):

Vitamin $\mathrm{E}$ theraby prevents hyperoxaluria-induced calcium oxalate crystal deposition in the kidney by improving renal tissue antioxidant status, Br.J.Urol.Int.96:117-126.

Ullah N., Khan M.A., Khan T. and Admad W.(2013):

Cymbopogon citratus protects against the renal injury induced by toxic doses of aminoglycosides in rabbits. Indian J Pharm Sci 2013; 75:241-246.

Xin Y., Kessarin P., Neil K. and Kenneth N.(2007):

Cisplatin nephrotoxicity. A review. Am. J. Med.sci.334:116-124.

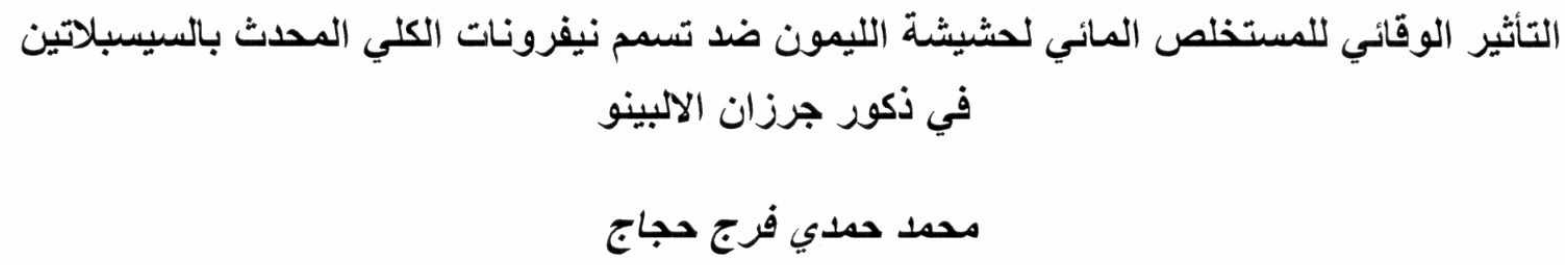

قسم التغذية و علوم الأطعمة ـ كلية الإقتصاد المنزلي - جامعة حلوان - جمهورية مصر العربية.

الملخص العربى

أجريت هذة التجربة بهذف دراسة التأثير الوقائي للمستخلص الماني لحشيشة الليمون ضد تسمم النيفرونات الكلوية المحدث

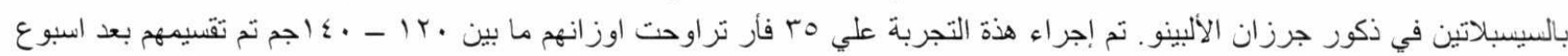

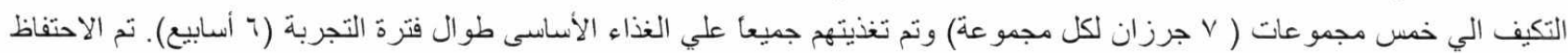
بالمجمو عتين الاولي والثانية كمجو عتين ضابطتين سالبة وموجبة علي التوالي. وتم تقديم المستخلص المانى لحشيشة الليمون للمجموعات

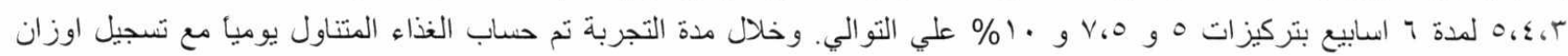

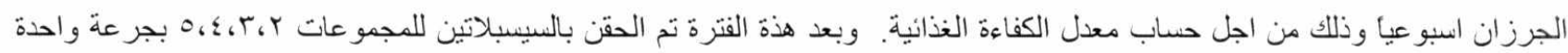

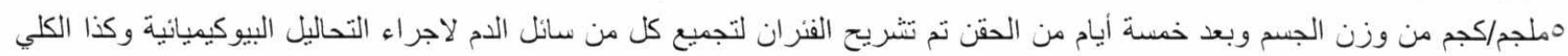
لاجر اء الفحص النسيجى.ايضا تم قياس مستوي كل من الـ

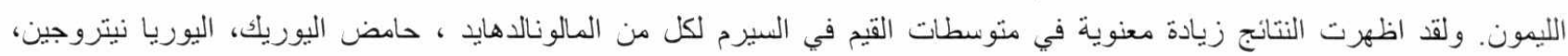

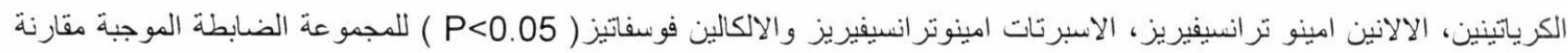

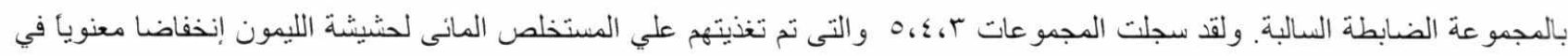

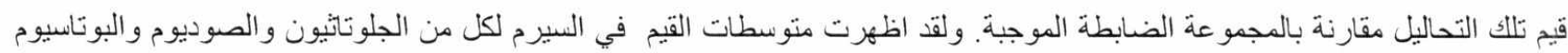

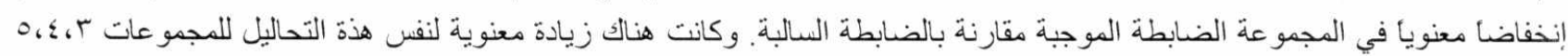

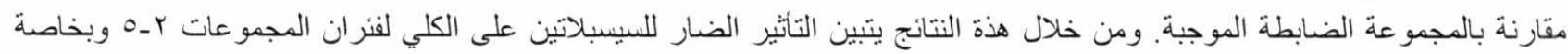

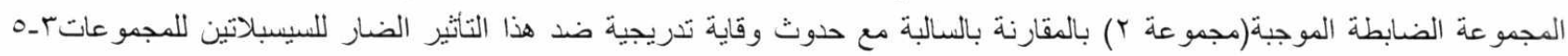

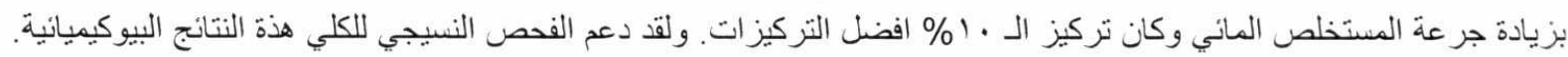

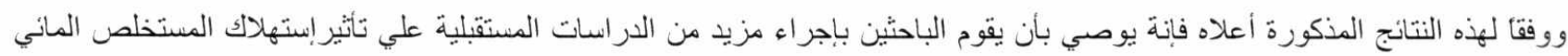
لحشيشة الليمون في حماية الكلي من التسمح في الإنسان. 